\title{
A Carefare Regime
}

Abstract Hungary's anti-liberal government has invented a novel solution to the care crisis, which I call a "carefare regime". This chapter describes four key features of the policies, policy practice and discourse that make up Hungary's carefare regime. I argue that in contrast to welfare state models familiar from developed democracies, in post-2010 Hungary, women's claims to social citizenship are most successfully made on the basis of doing care work. The state is re-engineered rather retrenched: services are not commodified but "churchified" in an effort to redistribute resources and build political loyalty. Women are constructed as "naturally" responsible for reproduction and care and this responsibility is tied to sentimentalized notions about femininity and true womanhood. In addition to providing care in the household, women are increasingly engaged in the paid labor market too, where the tolerance for gender inequality is officially mandated. A carefare regime provides limited financial advantages for a select group of women, while simultaneously increasing their devalued work burden both in and outside the household: it feeds a growing underclass of women workers.

Keywords Care crisis $\bullet$ Welfare regimes $\bullet$ De-familialization $\bullet$ Re-familialization $\bullet$ Carefare $\bullet$ Wage gap $\bullet$ Labor market $\bullet$ Gender inequality $\bullet$ Social citizenship $\bullet$ Demography $\bullet$ Family policies 
"And I hope that you-yes, you-have the ambition to lean in to your career and run the world. Because the world needs you to change it." Sheryl Sandberg, Lean in: Women, Work and the Will to Lead (2013)

"Do not believe that we, women must always compete with men. Do not believe that we must compete in every moment of our lives, or that we must have the same position, the same salary as them ... let's be happy that we were born women. ... Let's be happy that we were given the gift of being able to love and take care of others." Katalin Novák, Minister for Families in Hungary in a video message to women, (HVG 2020)

Over the past decade and a half the problem of the care crisis has gained traction in both the academic literature and in popular media (Ehrenreich and Hochschield 2004; Rosen 2007; Williams 2018). Recently, Nancy Fraser (2016) has argued emphatically that a "crisis of care" was looming in western capitalist societies caused by the increasingly unresolvable conflict between the logic of social reproduction and that of aggressive capital accumulation. Fraser points out that although capitalist production requires healthy, socially apt and highly skilled human beings to meet its ever-growing profit targets, the work that goes into producing these individuals and the communities in which they thrive, that is, the work of social reproduction, has become devalued to the extreme by the very same logic of accumulation. Financialized neoliberal capitalism, she claims, has aggravated the above contradiction to the point of an inevitable explosion, although Fraser muses about the possibility of the emergence of creative "mutant" regimes, which would offer temporary solutions to patch up evolving crisis tendencies.

Hungary's anti-liberal gender regime is such a mutant. I argue that since the mid-2010s the Hungarian government has been offering a novel response to the care crisis, one which is successful in generating a sufficient degree of political legitimacy even in the face of growing inequalities and social disintegration. I call Hungary's anti-liberal solution a "carefare" regime. Carefare is a form of state response to the care crisis, a set of social policies, policy implementation and related discourse within an anti-liberal political culture and an authoritarian capitalist economy. Carefare is not the only possible anti-liberal response to the crisis of care, but it is certainly one of them and a successful mutant at least in the short run.

Below I discuss in detail four features which jointly distinguish "carefare", Hungary's response to the crisis of care, from the generic model of 
Table 2.1 A comparison of the logics of carefare versus the "two-earner family" model

\begin{tabular}{|c|c|c|}
\hline & "Two-earner family" & "Carefare" \\
\hline $\begin{array}{l}\text { Basis for claiming } \\
\text { social citizenship } \\
\text { rights }\end{array}$ & $\begin{array}{l}\text { Social insurance and } \\
\text { means tests } \\
\text { Claims as individuals }\end{array}$ & $\begin{array}{l}\text { Care work is combined with waged work } \\
\text { Claims by heterosexual families }\end{array}$ \\
\hline $\begin{array}{l}\text { Extent of public } \\
\text { responsibility for } \\
\text { reproduction }\end{array}$ & $\begin{array}{l}\text { Disinvestment } \\
\text { Services are } \\
\text { commercialized }\end{array}$ & $\begin{array}{l}\text { Selective disinvestment } \\
\text { "Churchify" instead of commodify }\end{array}$ \\
\hline $\begin{array}{l}\text { Responsibility for } \\
\text { care work }\end{array}$ & $\begin{array}{l}\text { Either externalized to } \\
\text { family or commodified } \\
\text { by global care chain } \\
\text { Reproductive work is } \\
\text { seen as a yoke that } \\
\text { holds women back }\end{array}$ & $\begin{array}{l}\text { Falls on native women, absolutely not on } \\
\text { immigrant labor } \\
\text { Reproductive work within heterosexual } \\
\text { working families is what gives meaning to } \\
\text { life for women and is their responsibility } \\
\text { toward their families/the nation }\end{array}$ \\
\hline $\begin{array}{l}\text { Who works for } \\
\text { wages? } \\
\text { Is gender equality } \\
\text { important? }\end{array}$ & $\begin{array}{l}\text { Women are expected to } \\
\text { work, and "lean in" } \\
\text { Equality measures exist } \\
\text { Diversity is celebrated }\end{array}$ & $\begin{array}{l}\text { Women are encouraged to work but not } \\
\text { "lean in" } \\
\text { Gender equality policies are rejected, } \\
\text { replaced by sentimentalization of work } \\
\text { Gender inequality is acceptable }\end{array}$ \\
\hline
\end{tabular}

the "two-earner family", found, with variations, in numerous western countries guided by principles of neoliberalization (Fraser 2016; Walby 2020). None of the elements of carefare are particularly new. Indeed, several authors point out the direct links and similarities between elements of anti-liberal and neoliberal governance (Jessop 2019; Scheiring 2020). Yet the combination of these features results in a unique discursive interpretation of the care problem and a set of social policies, which do, in fact represent a novel answer. Table 2.1 below summarizes the four set of features in comparison. After a short discussion of the history of anxieties about the size of the population in Hungary, I explain and provide evidence for each in the rest of this chapter.

First, in a neoliberal capitalist welfare state, successful claims on the state are made on the basis of social insurance and, secondarily, material need. These constitute the bases of social citizenship. Doing unpaid care work does not carry a social insurance scheme, and claims to the state cannot be made on the basis of raising children, or being good parents. This is indeed the crux of the conflict between production and reproduction (Fraser 2016). In Hungary, however, care work has become a centrally important axis of social citizenship claims. Second, anti-liberal states are 
powerful and extensive, unlike their neoliberal counterparts which tend to disinvest in general and in social reproduction in particular. Hungary's anti-liberal state has increased already generous funding for several important aspects of social reproduction. In addition, instead of commodifying and marketizing previously state provided services in an effort to cut costs, it directs centralized state funding in a way as to maximize not profit or cost-cutting but political loyalty. Third, in Hungary care for children and the elderly is enthusiastically and selectively familialized. State policies assign care work to women and identify the heterosexual family home as its principal location. In neoliberal regimes, care work is increasingly outsourced to vulnerable, often immigrant domestic workers, to marketbased providers, and/or to state institutions. The main focus of policy objectives is typically to ensure that native, working age women do less care work, while in Hungary the opposite is the case. A political discourse which associates care with women's "natural" essence supports this process. Fourth, in addition to doing care work in the home, women are also incentivized to do waged work. This is done through tying reproduction related social benefits to work history and family income levels in addition to care work. This necessitates a dual earner couple. But state provisions do not address work-life balance problems, and gender equality measures are summarily rejected by Hungary's anti-liberal political leaders. A truly vicious trade-off is emerging where women must accept inferior work conditions in exchange for the possibility to meet care responsibilities. This is especially problematic for women in the lower educational brackets and those living in rural areas where work options are limited.

One consequence of carefare is obvious: it increases women's work burden while leaving men's untouched. In addition, carefare reinforces and exacerbates class inequalities because better-off families can utilize more of the income-based provisions than those with lower wages. At the same time, however, the logic of carefare rearranges patterns of socio-economic disadvantage at the bottom of the social hierarchy too. Pronatalist provisions boost the wellbeing of specific working class groups: those who have several children and some semblance of formal employment. These families have suffered vast social disadvantages in the past. Carefare promotes them into the category of "deserving families" and legitimizes their successful claims to social benefits. It is to these families that some of the economic growth gains and EU funding trickle down, even amidst growing overall social inequalities. If authoritarian policies serve as a political strategy to overcome conflicts generated by the growing inequalities of 
neoliberal capitalism (Scheiring 2020), carefare serves the same purpose via different means.

\section{“Care Crisis" as a Demographic Crisis in Hungary}

Hungarian policy makers have long acknowledged a pervasive crisis of care but only in one area of reproduction: the declining number of births to Hungarian women which they closely associated with the impending death of the Hungarian nation. Indeed, defining the declining birth rate of the native population as a "demographic crisis" is well known in European Union-wide thinking as well, although policy recommendations from the EU include a variety of measures which could potentially reduce the burden of care work on women. As I will show below this was not the direction the Hungarian government took.

To understand this rather narrow re-conceptualization of the problem of care, we need to understand the lengthy history of deep-seated anxieties about the size of the population in the country. Hungary is a small country of about 10 million people and this number has been shrinking steadily since 1981. The total fertility rate (TFR) has not reached what is typically considered sufficient for reproduction since 1959 (KSH 2019a). In this regard, Hungary's demographic characteristics are quite similar to those of many other post-socialist countries, which started to experience a decline in births in the 1950s. This then continued steadily throughout the twentieth century with a sharper drop in the fertility rate in the early 1990s after the collapse of state socialism, which brought about a deep economic crisis and major societal upheaval. Two decades later, the recession of 2008 produced even more societal stress all over the region and resulted in a further decline in fertility in the first decade of the twenty-first century. Soon, however, total fertility rates began to increase in all poststate socialist countries, with Hungary lagging somewhat behind, but picking up speed by 2013. In 2019, Hungary's total fertility rate was in line with that of the EU 27, even if the number of births had not shown a similar increase due to the smaller size of the cohort in reproductive age in the late 2010s (Eurostat 2018a; KSH 2019a).

Although Hungary's fertility rate is not significantly different from that of other Central and East European countries, or even the EU 27 average, the country's crude death rate is one of the highest in the European Union, and life expectancy, as well as healthy life expectancy, is one of the lowest (Eurostat 2018b). Indeed, all Visegrád 4 countries exceed Hungary 
in life expectancy and only Romanian and Bulgarian women die younger than Hungarians within the Union (ibid.). On the plus side, this is one of the reasons why Hungary's old age dependency ratio is somewhat lower than the EU average of roughly 30\%. Hungarian policy makers have mostly ignored the problem of early deaths and conceptualized the demographic crisis primarily as a threat to Hungarian nationhood and only secondarily as a potential human resource shortage.

\section{Anxieties About Populations}

Biopolitical concerns about the size and quality of the population have long plagued Hungarian political discourse (Melegh 2019). The country lost a great deal of its territories and over half of its population following World War I-some to the damages of the war itself, most to the dictates of the post-war Treaty of Trianon. The pain of the war loss intensified debates about demography and specifically about the phenomenon of the "single child" popular in rural households in certain regions in Hungary (Andorka 1975). The anxiety about the size of the population was explicitly connected by politicians, writers and public figures alike with the future of the Hungarian nation and the looming threat of German invasion (Heller et al. 2015).

After World War II even though war losses were significant, discussions about demography were silenced for a while, as issues related to industrialization, war recovery and an ideological commitment to the fight of the international rather than the national proletariat were considered more important by the leaders of the Communist Party. However, by the middle of the 1950s, when the post-war baby boom failed to materialize in Hungary, the government decided to take a radical step and banned abortions altogether (Pongráczné 1999). The number of births increased temporarily but political pressure forced the government to abandon the measure in 1956. In the absence of other types of contraceptives, abortion became the primary form of birth control for Hungarian women: between 1960 and 1973 the number of abortions, legal and accessible, exceeded the number of births (KSH 2019a).

After the revolution of 1956, the Hungarian government's population policy started to lean toward incentives rather than prohibition. In 1967, a three-year paid maternity leave was introduced as a way to encourage births and also to regulate the labor market. But as a backlash against permissive abortion regulations and the extremely high number of 
procedures, the government created a new population policy in the early 1970s, which added a set of restrictive measures as well. Around this time an extensive public debate took place on the pages of Hungarian magazines and weeklies. Public figures, writers, sociologists and demographers expressed concern about the developments in population trend, linking the problem of fertility decline to classic tropes ranging from the death of the nation and the disappearance of Hungarians from the planet, to moral concerns about abortions, the idyllic image of large healthy families of the past, as well as to the relationship between women's emancipation and labor force participation and their willingness, inclination and ability to produce more children (Heller et al. 2015). Current definitions of the problem of care resonate deeply with many of these ideas.

Population concerns were not limited to Hungary, of course, but in the 1970 s and 1980s the primary global concern was the "population bomb" rather than depopulation. It was after the turn of the twenty-first century that the issue of demography came to the attention of policy makers in the European Union. ${ }^{1}$ As the first cohort of baby boomers entered retirement age and looked forward to decades of happy retirement, the notion of old age dependency came to be conceptualized as a looming problem. The size of the EU's population started to shrink in 2015 prompting further discussions about depopulation, the cost of aging and population projections.

Although nationhood, national identity and demography had been points of interest for the Orbán government immediately after its accession to power in 2010, it was the refugee crisis of 2015 which cast the population problem in an altogether different light and allowed it to gain the political momentum to profoundly change social policy. In the summer of 2015, a large wave of refugees entered Hungary. In average years about 2000-3000 people sought asylum in the country, by early fall of 2015 the number was close to 180,000 (KSH 2019b). Refugees from Afghanistan, Syria, Pakistan, Iraq and Kosovo arrived in Budapest, submitted their request for asylum status but moved on toward more prosperous and inclusive parts of Europe, such as Germany, France or the UK. The flood of asylum seekers entering the EU through the Serbian-Hungarian border took the country by surprise and no humanitarian support was

\footnotetext{
${ }^{1}$ I want to thank Zsolt Spéder (head of the Hungarian Demographic Research Institute) for his lengthy consultation with me on topics related to population policy in Hungary and globally. See also Melegh (2019).
} 
forthcoming. Instead, the Hungarian government constructed the notion of the "refugee crisis", built a wall to restrict entry on the southern border and started a country-wide propaganda campaign which depicted refugees and migrants as potential terrorists and threats to the social and cultural wellbeing of all. A second propaganda campaign demonized George Soros, and argued that he, with the complicity—even direct assistance - of key politicians in the European Union encouraged and funded migration in an effort to destroy the purity of European Christianity. Hungarian politicians were not ashamed of their openly racist and xenophobic messaging which had the expected influence: Hungarians developed a real and measurable fear of the person of the "refugee", even though most of them had never actually met one in their lives. Within three years, the number of asylum seekers plummeted to levels well below those pre-2015, yet the government kept up its anti-immigration xenophobia.

It is against this backdrop that Orbán's government decided to tackle the crisis of care by foregrounding the problem of the demographic crisis at the cost of any other issues related to the problem of care. "We want more children, not migrants" said Hungary's prime minister as part of his re-election campaign in March 2018 (Erdély.ma 2018), and Hungarians found this call appealing. In 2018 Orbán won his third election victory and gained a qualified majority in Parliament. The scene was set for the final development of the carefare regime.

\section{Social Citizenship Claims in Carefare Regimes}

In her now classic account of the history of the Hungarian welfare state, Lynne Haney (2002) notes a shift around 1985 in the "architecture of need" that underpins the logic of social citizenship. Before the mid-1980s claims to the state socialist welfare state were most successfully made on the basis of maternity. State socialist social policies and centralized redistribution guaranteed that women with the same number of children received the same amount and types of subsidies regardless of other circumstances, such as need or work status. In my previous work I argued, in agreement with Haney, that women during state socialism were constructed as a "corporate" group, with specific skills and unique contributions to society, typically maternity. This guaranteed specific rights and privileges, different from those of the group of men (Fodor 2003).

But in the mid-1980s these "maternalist" principles changed toward what Haney calls "materialist" ones. She argues that instead of 
motherhood, material needs came to be seen as the basis of social citizenship: new measures were introduced that targeted the group newly defined as needy, state provisions were allocated on the basis of material need, evaluated by local rather than central governments and in a way that differentiated among women, rather than offering similar support to all in the same care work or parental category. Means tests were utilized and benefits favored those who had paid social insurance, although benefit levels differed according to other characteristics too, such as the length and type of previous employment or education. Overall, subsidies were cut back significantly, or they lost their real value in the context of inflation and became subject to political struggles. "Child rearing was no longer considered a social responsibility deserving remuneration; women were no longer guaranteed compensation for their maternal labor; and claims to state assistance were no longer framed around one's contribution as a worker, mother, or family member ... women would be recognized only as 'needy' individuals" (Haney 2002: 189).

"Materialist" welfare principles are part of the logic of neoliberal statecraft; and neoliberal-leaning capitalism was understood in the early 1990s as the brightest possible future for the country. Notably, as distinct from membership in the corporate group of women (i.e., potential, present or past mothers), neoliberal citizenship rests on the notion of the individual. As Rose (1998: 165) put it, "The political subject is ... an individual whose citizenship is manifested through the free exercise of personal choice amongst a variety of options". Individuals are expected to develop their human capacities in order to compete successfully on various markets and they must strive to rely on these markets to satisfy their needs. The state is of minimal importance, providing financial support only in cases of dire need.

Anti-liberal Hungary moved away from this individual-based principle of social citizenship. In Orbán's "carefare" state claims to the state can again be made on the basis of membership in a community, specifically the family and, indirectly, the nation. (This is not the only basis of claims making but certainly a new and very significant one.) In the words of László Kövér, the President of the Hungarian Parliament, "Who is a decent Hungarian citizen? Not someone who speaks Hungarian. It is someone who has 3-4 children, 9-12 grandchildren, they all speak Hungarian and are committed to the Hungarian nation" (László Kövér's speech in Gyergyószentmiklós, August 2019). In his interpretation, citizenshipincluding social citizenship - is based on active membership in a fertile, 
populous family. Government policies have been duly transformed to reflect this principle.

A quick review of the regulations introduced between 2014 and 2020 makes clear the explicit goal of encouraging childbearing-as well as the additional requirement of parents' participation in paid work. I have enumerated the very long list of the main policies - both new and old-in the appendix. Column 1 identifies the basis of receiving the benefit. Note that the state has eliminated, shortened, cut or devalued all universal cash benefits paid to people as a citizenship right. As an example, see the backbone of family protection legislations since the mid-1960s, the flat rate threeyear parental leave allowance (line 3 in the table in the appendix). For the past several decades this has been the main social benefit available to new parents, which allowed mostly mothers to withdraw from paid work for up to three years after childbirth to raise children. Parents receive a lump sum payment, retain social insurance and the promise of their jobs back upon return. Parental leave is an extremely popular measure in Hungary, where the majority of the population is convinced that children do best if they are raised at home by their mothers until age 3 (Blaskó 2011). Only one government attempted to abolish the three-year leave as part of a broader austerity package, but the policy was soon reinstated. The actual sum the participating parent receives equals the minimum old age pension in Hungary, which has been set at 28,500 HUF (or less than 80 EUR) since 2008. At that time in 2008 , the parental leave benefit represented $41 \%$ of the national minimum wage, while in 2020 it amounts to only $18 \%$ (and about $7 \%$ of the average wage). To counter any hope that this may be adjusted, the government additionally passed a regulation which essentially froze the value of the minimum pension/parental leave benefit at this level forever (Government decree 707/2020. (XII.30); Portfolió, 2021). At the same time a different type of parental leave benefit has been raised generously: the one that mothers with formal employment can claim for the first six months of their leaves. The government has boosted the value and conditions of insurance-based parental leave options, while allowing the universal flat-rate benefit to devalue.

To complement the parental leave allowance, the "family benefit" has served to support families raising children since before World War II. The regulations and eligibility criteria of the family benefit have changed several times over the years, but it has been a universal support scheme since 1998 (Spéder et al. 2020). However, its value has fluctuated significantly. At the end of the state socialist period in 1989 it represented $21 \%$ of the 
average wage per child, which was a significant contribution to the family budget. It was devalued after 1990, then adjusted during the reign of the Socialist government in 2008. Since then, neither the Socialist government in power until 2010, nor Orbán who took over in the spring of that year, has changed the amount of support allocated per child. This means that in 2019 the benefit for a single child amounted to less than $5 \%$ of the average net wage (author's calculations based on data from Central Statistical Office, and Jarvis and Miklewright 1992). Both major universal benefits - the three-year parental allowance and the family benefit-which people receive without consideration of class or work status have lost a significant portion of their values and the government has announced that it has no plans to change this. Several other types of social provisions met the same fate (Scharle and Szikra 2015).

Successful claims on the state are nowadays made on the basis of significant care work combined with some employment history. Claim makers are typically "families" (defined as heterosexual married couples with children and employed in the formal economy) rather than individuals. The first and most significant of new family benefits is the earned income tax credit, which was re-introduced in 2011 . On its official webpage, the government describes it as reflecting two basic values: "work and childcare done in addition to paid work". Note the emphasis on the combination of care work and paid work-this is certainly not a traditional "back to the kitchen" ideology! Working parents can claim a portion of their taxes back, which in 2021 could yield, at the maximum 33,000 HUF per month (about 100 EUR) per child if a family has at least three children. The tax break is significantly smaller per child if the family has fewer children, which is not surprising since the government has an openly pronatalist agenda and the measure is meant to encourage childbirth. The goal is in fact noble: demographers had long argued that Hungarians wanted more children than they would actually end up giving birth to, so the government claimed that it sought to redress this problem and enable families to have as many babies as they desired (Kapitány et al. 2019). But earned income tax credits can only be claimed by those in formal employment, and informal work arrangements are widespread in Hungary (Hegedüs 2020). In addition, the total family income from formal employment must exceed a certain level, otherwise parts of the tax break are lost. In 2019, families had to have a joint income of at least 330,000 HUF, which was about $10 \%$ lower than the average gross wage for full-time work for one person. Recent studies, however, show that about $40 \%$ of employees are 
registered at the minimum wage in Hungary, although they may or may not receive additional income "under the table" (Hornyák 2019). The minimum wage was 149,000 HUF per months in 2019, so even two parents working full time on the minimum wage were not eligible for the full sum. If parents divorced-and about a third of marriages end up in divorce in their first 15 years (Makay and Szabó 2018), only one party can claim the tax credit, typically mothers, whose income alone may not be enough to receive the full sum. Nevertheless, a significant number of families can and do utilize these earned income tax credits-the precise number is simply not available. Those without employment or formal employment are not eligible. Following a similar logic, working mothers of four or more children do not pay income tax - a benefit that is tied to both paid work in the formal economy and significant care work responsibilities.

In addition to the tax credit, married couples can take a variety of loans which do not have to be paid back if they give birth to the requisite number of children. The centerpiece is a 10 million HUF loan (about 27,000 EUR, introduced in 2019) for couples who plan to have children. The loan can be used for any purpose and a portion is forgiven after the second child. It turns into a non-repayable grant once the third child is born. Couples do not pay interest in the first five years, or at all once they have their first child. Significantly, this is a loan, which can only be taken if at least someone from the family has a three-year work history, a sizeable formal income, and if the couple is married. Its value, as must be obvious from the above, far exceeds that of the flat rate family benefit.

A second set of provisions helps "families" buy, build or renovate their homes. If married couples promise to have children, they become eligible for a grant to be spent on real estate, the size of which is dependent on the number of children they have, or promise to have, and the qualities of the home. There are additional subsidized loan opportunities, mortgage reduction and a handful of other variations on this benefit. The main point is that they are all tied to employment, being married if the couple has no children yet, age (she has to be under 40 ), and the couple must have significant resources of their own because the state subsidies are not enough in and of themselves to buy/build or even renovate any real estate. Interestingly, there is a special provision for those who want to build a multigenerational home, which the government encourages and offers special subsidies for. Grandparents are encouraged to be involved in care work via other means as well: they can take parental leave instead of the 
birth parents of the child. In that case, however, not only the grandparent but both parents of the child must be insured, thus working for wages.

All combined these provisions target married couples with some formal employment and savings of their own, who have or plan to have at least two or more children. The sum they can claim from the state is sizeable, while provisions available outside this social category are lower and disappearing. In Hungary's state socialist "maternalist" welfare regime, mothers of all social categories received similar benefits regardless of employment, marital status or social class. Social citizenship claims in Hungary's carefare regime, on the other hand, are conditioned on a combination of criteria related both to formal employment and to unpaid care work done within a married couple family.

\section{Selective Disinvestment and Churchification}

What Peck and Theodore (2012: 179) call "the prosaic and frequently tawdry practice of [neoliberal] deregulatory statecraft" typically involves disinvestment in social protection measures, and the decentralization and commodification of formerly state provided services. David Harvey (2015) goes even further to claim that neoliberal states have become active agents in capitalist "accumulation by dispossession" and under the pretext of deregulation seek to create a favorable climate for business interests, protect the integrity of financial institutions over community interests, and redistribute wealth in a way to keep large segments of the population impoverished and corporate capitalist greed satisfied(Harvey 2015). In this context it is the "overgrown penal state", which keeps the poor under control, and thus neoliberalism "entails not the dismantling but the reengineering of the state" (Wacquant 2012: 6), specifically "marketconforming" state crafting. This is a political rather than an economic project, in which the state re-regulates the economy, commodifies existing services, imposes disciplinary social policy to replace both welfare and workfare systems, and uses penal policy and the discourse of individual responsibility to keep people in line (ibid.). It is in this context that the crisis of care becomes more apparent than ever. The exclusive emphasis on profit leads to a devaluation of reproduction, and reduces support for the birthing and raising of children, caring for the sick and the elderly, and maintaining social ties which hold together families and communities (Fraser 2016; Isaksen et al. 2008). 
In good neoliberal fashion, the Hungarian state has also withdrawn funds from social protection in the past decade. In 2010, Hungary dedicated $17.4 \%$ of its GDP to social protection expenditure, which was reduced over the years to $13.3 \%$ by 2018 , while the EU-27 average remained stable at roughly 19\% (Eurostat 2019a). Indeed, as Prime Minister Orbán pointed out, the aim of the Hungarian government was to transform Hungary from a welfare to a workfare state, which meant reducing need-based provisions to the bare minimum, and securing workplaces to those willing and able. Following this logic, the Orbán government invested in developing a public works program which soon grew to be one of the largest in the world, and, as noted above, cut cash payments of all varieties, replacing some with benefits in kind. The length and value of the unemployment benefits was decimated, access to long-term sick pay became cumbersome and the value of a variety of social provisions to the needy was devalued. OECD statistics confirm that the proportion of the country's GDP spent on cash transfers decreased significantly while inkind services have remained stable since 2010 (OECD 2019).

Up to this point, a familiar picture is presented: parts of the world exposed to global neoliberal economic policies and the structural adjustment requirements of international financial organizations often follow these patterns. In fact, this strategy is not altogether different from what several rather liberal Hungarian governments had pursued in years prior to Orbán's accession to power. On closer inspection, however, one important distinction emerges. In 2019, Hungary and Germany were recorded as the two countries within the EU which spent the largest share of all social protection costs, $12 \%$, on a specific function, namely "family protection". When the costs of earned income tax credit are added, Hungary is one of the world leaders in this regard (Makay 2018). To be clear, family protection is euphemism for pronatalist policies offering incentives to heterosexual Hungarian families to have more children. So while spending on other areas of social protection, such as welfare and unemployment declined, "families" have been targeted with generous support. (The quotation mark is a reminder that only one specific form of household is considered a family: heterosexual couples with children and with some form of paid employment.) The government has been funding this specific area of reproduction generously. Although this is just one segment of care work, it is an important one, and one which demonstrates that instead of neoliberal state retrenchment, in Hungary we are witnessing the reorganization of state capacity in line with specific political goals. 
Critiques of neoliberal governance note with alarm the increase in deregulation of state services in western economies. A curious alternative has been emerging in Hungary. First, certain state services have in fact expanded: the government has been building nursery schools and has increased access to state provided childcare. Although a small number of private providers are also on the market, their share is insignificant: fewer than $10 \%$ of children spend time in paid day care (KSH 2019c).

In other areas, the state is in fact deregulating, but favors only a specific type of provider: a handful of trusted churches. In this case the goal is not to cut costs, as the state funds these services more generously than it does its own institutions. Instead, the goal is to build political loyalty for present and future generations. Churches have played a growing role in social services in Hungary since the collapse of state socialism, but their participation has increased exponentially in the past decade. By 2020, churches ran about $25 \%$ of homes for the elderly and the disabled, provided $45 \%$ of all basic social services, and $60 \%$ of all child protection services (Magyar Nemzet 2020, quoting the Minister for Social Affairs). Care in these institutions is not paid for by donations from members of the church community. Instead, the Hungarian state allocates resources to a small number of established churches to provide the same service as the state or civil organizations do. Only churches receive more funding per capita than a state or non-governmental provider would and they are not obligated to spend all of the money on the actual service in question. By a recent decree, the largest churches also receive the property rights of the institutions they run, cementing their role in the field and allowing them space for independent economic activities. The lack of separation of the church and the state is especially poignant in primary and secondary education, where religious schools have multiplied at the cost of funding good quality secular public institutions. In 2001, fewer than $5 \%$ of children attended schools run by churches. In $2019,15 \%$ of primary school students and $25 \%$ of secondary school children did so. While in western liberal democracies engaging forprofit and non-profit providers allows states to control and cut costs, in Hungary state services are not commodified or marketized but churchified: increasingly overseen by politically and ideologically loyal religious organizations, which preach a specific ideology, and support the sustenance and reproduction of an anti-liberal political order. 


\section{Women Do Care Work in "Families"}

"I would like to make a deal with Hungarian women, Hungarian ladies, about the future and their role in it as well as the new opportunities the government could offer", suggested Prime Minister Viktor Orbán in a radio address on the national radio channel in April 2018, soon after his third election victory. His offer clearly reflects a key principle of the new pronatalist policies he was referring to: having children is women's job, women's decision, they are the ones responsible. Since women are expected to do the work of birthing and caring for children, the prime minister's offer addresses women and women alone. The third feature of carefare regimes is the unashamedly unequal distribution of care work and the emphasis on the household as the location for care.

The literature on the de- and re-familialization of care is extensive (Mahon 2002; Morgan and Zippel 2003). Familialism denotes policies, which encourage care, especially childcare, to be carried out within the family. The opposite of the concept is de-familialization, that is, when policies encourage the outsourcing of care and thus open up space for women's successful participation in paid work, the two-earner family (Javornik 2014). Tendencies of re-familialization have been observed in most post-communist societies and several typologies exist to describe different types of policy packages (Fodor et al. 2002; Haney 2003; Javornik 2014; Rat and Szikra 2018; Saxonberg and Sirovatka 2006; Szelewa and Polakowski 2008; Szikra and Szelewa 2010). These studies typically take into account two large sets of policies-parental leave and the availability of childcare-and show how various combinations offer different options for women. Some encourage them to do care work at home, others to work for wages and send children to childcare institutions, while yet others allow families to choose between these two options. My argument is that in Hungary's carefare regime women are assigned care work and care is primarily relegated to the home, and simultaneously, they are expected to work for wages full time. The conflict between reproductive work and work is solved via women's increased work burden and exploitation.

Hungary's recent "family protection" policies aim to increase the number of births. While most demographers agree that they are unlikely to raise the total fertility rate to the point of replacement, the policies could, at least temporarily, increase the birth rate in at least some segments of society (Spéder et al. 2020). Indeed, following the introduction of the tax credit-based benefits, in 2014 the number of births increased in Hungary, 
and after a drop, picked up again in 2020. Birth rates have grown fastest in the poorer regions of the country, while the decline in births continued in the capital of Budapest (KSH 2020).

As the number of births per woman increased between 2010 and 2020 from a low of 1.33 to 1.5 and is likely to grow further, families' reproductive burden is also expected to become heavier. And, as time budget surveys indicate, the brunt of this extra work will most likely be shouldered by women. In 2010 , the year for which the most recent data are available, mothers of two children, living with their spouses, spent 96 minutes a day on childcare (while their spouses also dedicated 37 minutes to this task). But in families with three children, mothers spent an additional $82 \mathrm{~min}$ utes more a day on childcare, over three hours altogether, while fathers of three children only did 15 minutes more than fathers of two. The extra care burden of another child is clearly carried by women (Falussy and Harcsa 2000)and even if we count the gender difference in the length of paid work, mothers had about an hour less free time per day than fathers in 2010 (KSH 2012).

Mothers' burden is likely to increase especially as intensive mothering is becoming more popular in Hungary too. In a small survey we conducted in 2020 during the COVID-19 pandemic, we found that while all mothers increased their care work during the lockdown months more than fathers did, educated urban mothers' workload grew about four times more than the average (Fodor et al. 2020). In general women at all levels of education spent more time than fathers helping their children with school work and educated women especially seemed to have internalized the expectation of intensive mothering and the notion that they were responsible for making sure their children were not left behind (Geambasu et al. 2021).

More children thus mean more work, and that work will most likely be women's responsibility. While a great deal of propaganda is dedicated to encouraging women to have more children, no mention is made of men's role in carrying at least some of the care burden. The Hungarian government has made several generous adjustments to parental leave benefits which are almost exclusively used by women. However, it did not increase the length of paternity leave from five working days, which is significantly lower than the EU average of 12.5 days.

Welfare typologies usually consider the division of labor with a nuclear family - type household in mind (although see Utrata 2015). In Hungary, familialization has traditionally included the mobilization of grandparents 
for care work as well. Although the proportion of multi-family households has declined in Hungary over the past 50 years, still about $23 \%$ of women and $18 \%$ of men over 65 live with their offspring (Monostori and Gresits 2018). Most grandparents are heavily involved in the care of children: in 2016, two-thirds of 55-79-year-olds participated in this activity. The younger, healthier and more educated they were, the more likely it was that they helped out (ibid.): an impressive $80 \%$ of college-educated grandparents looked after small children in Hungary in 2016. Interestingly, in this age group there was little gender difference: grandfathers were almost as likely to take care of children as grandmothers (ibid.). Building on this tradition of multigenerational care, the government has created financial incentives for grandparents to take parental leave instead of their children, and is offering special support to those who seek to build multigenerational households and to retain care responsibilities within it. In return, the government enshrined in the Constitution of 2011 the obligation that children take care of their elderly parents in need. This, obviously, is another glaring instance where care is familialized, although not via incentives but legal decrees.

In conclusion, in Hungary's carefare regime mothers are primarily responsible for care work in the home. A very small number of families can afford to rely on paid help, although more take advantage of grandparents' availability. The government's pronatalist policies have already resulted in the birth of more babies and this is likely to continue. There is no public mention of the fact that having more children will surely increase women's care work load.

\section{BEYOND “BACK TO THE KITCHEN": WOMEN as Wage Workers}

The fourth feature to note in Hungary's carefare regime is the one least discussed in the literature: the necessity for women to be engaged in paid work in addition to producing additional Hungarians for their families and the nation. As I showed above, benefits claimed on the basis of care responsibilities are also tied to employment history, either explicitly or because they require a level of income which is only achievable by two earners. In addition, specific targeted regulations directly encourage women's return to work. For example, in 2014 a change in parental allowance was introduced, which means that women can now keep receiving the 
allowance even if they go back to work and, unlike before, they can work full time. Employers too have long had some incentives to hire women with small children through a reduction in taxes on labor. This distinguishes Hungary's anti-liberal carefare regime from European conservative welfare arrangements, such as, for example, in Germany or Austria (Shire and Nemoto 2020). In this carefare regime the "male breadwinner" model or the notion of the family wage are not ideals to be followed, quite the opposite.

In Hungary, women have long been permanent participants in the labor market, and their wages have been essential for the family budget. At the same time, women are also responsible for care work in the home: they drop out of the labor market for lengthy periods after childbirth and dedicate significantly more time than their spouses to the daily chore of raising children and doing other types of care work. This necessarily limits their opportunities in paid work, puts them in a precarious position in the labor market, and occasionally forces them to accept trade-offs between wages and the ability to meet their reproductive responsibilities (Mandel and Semoyonov 2006; Petit and Hook 2009). Two issues clearly differentiate carefare regimes from others which encourage a dual wage earner model. First, the stated goal of achieving gender equality in the labor market is missing in Hungary as are policies which require that employers, including state employers, guarantee transparent and reliable work-life balance measures. Second and related, instead of equality legislation or workers' representation, women's work is "sentimentalized": women are constructed in official political discourse as primarily carers, even in the workplace. Care work is devalued and, as elsewhere, it is understood as part of women's true feminine identity, not as part of their job description (England 2005; Hochschield 1983).

The combination of these two factors - sentimentalization and the lack of gender equality/care work reconciliation measures-result in an increase in the "motherhood penalty", that is, the disadvantages mothers suffer at work, and exacerbates workplace gender inequality, especially at the bottom of the social hierarchy. It leads to the emergence of an underclass of women workers, who may have the opportunity to be earning an income in humiliatingly underpaid jobs but must struggle on a daily basis to hold on to their positions and manage their care responsibilities simultaneously (Gregor and Kováts 2018, 2019). I will start with a discussion of this latter phenomenon. 


\section{An Underclass of Working Women}

Paid work opportunities soared after 2015 as the Hungarian economy, partly fueled by payments from the European Union's structural funds, picked up speed in the aftermath of the economic recession. In 2019, the unemployment rate stood below $4 \%$ and remained under $5 \%$ even during COVID-ridden 2020. As Fig. 2.1 shows, both men and women were able to find work and while in the early 2010s Hungarian women's labor market participation rate counted as one of the lowest within the EU, by 2020 it had climbed to average levels (Eurostat 2019b).

Two points are important here. First, women's employment growth seems to be slowing after 2012: the gender gap in employment started to widen slowly but perceptibly. Indeed, Eurostat data indicates that, compared to men, women in Hungary are less likely to be able to transition from unemployment to employment. This is true for most countries but the gap in Hungary was five percentage points in 2019 (as well as in several prior years), which is twice the EU-27 average, and higher than in other CEE countries (Eurostat 2019c). The COVID pandemic further increased the difference in the number of employed men and women (KSH 2021).

Second, the gender gap in access to paid work is particularly large among those with lower levels of education, that is, at the bottom of the

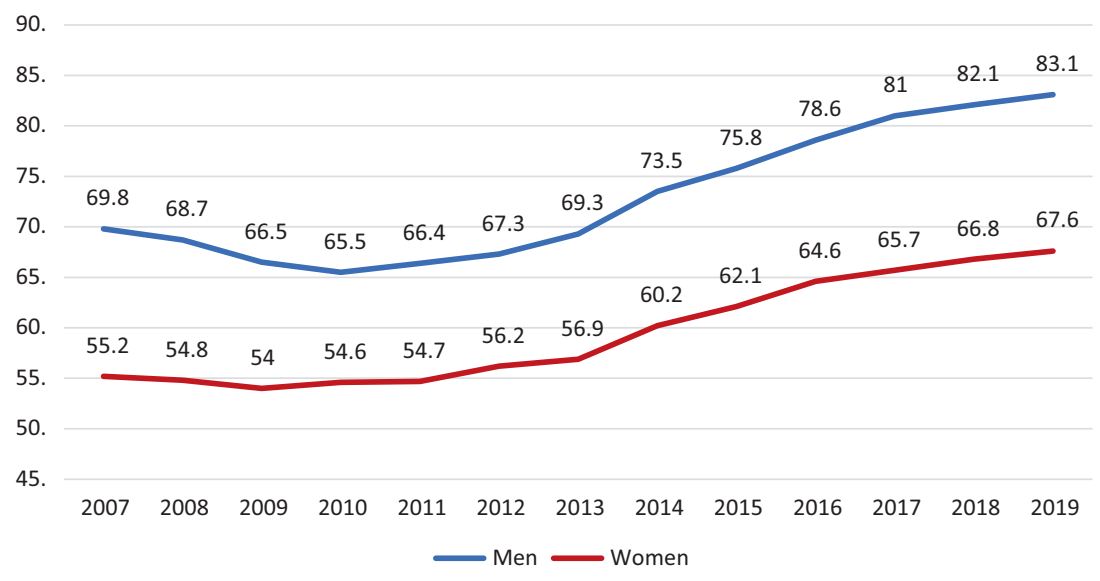

Fig. 2.1 Changes in men's and women's employment rate, 15-64 year-olds. (Source: Eurostat 2019c) 
occupational hierarchy and there are significantly more women than men in this group. But the number of employed women in this category has been growing. While in 2011 only about $31 \%$ of women with elementary education were working for wages, this percentage increased to $46 \%$ by 2019-a close to 50\% growth, larger in absolute numbers and percentage terms than in any other educational groups (ibid.). This is the underclass of women workers I mentioned previously. Working for wages is not all bad. Employment opened up new, if rather limited, financial opportunities for women at the bottom of the occupational hierarchy. It, however, also exposed them to more gender inequality, more work and harsher exploitation.

Women's wages are lower than men's in Hungary and women in the lower educational category experience roughly the same wage gap as the national average of $16 \%$ (Eurostat $2019 \mathrm{~d}$ ). Lower wages are less likely to help pull someone out of poverty and this is what we see in Fig. 2.2. Women's at-work poverty risk had been lower than men's until 2015, after which it started to exceed men's. Working women's risk of poverty doubled from $4.6 \%$ in 2010 to $8.7 \%$ by 2019 and exceeded men's which stood at $8.1 \%$ in 2019 (see Fig. 2.2, based on Eurostat 2019e). In other words, parallel to the mass entry of women into low level jobs, the risk of in-work

12

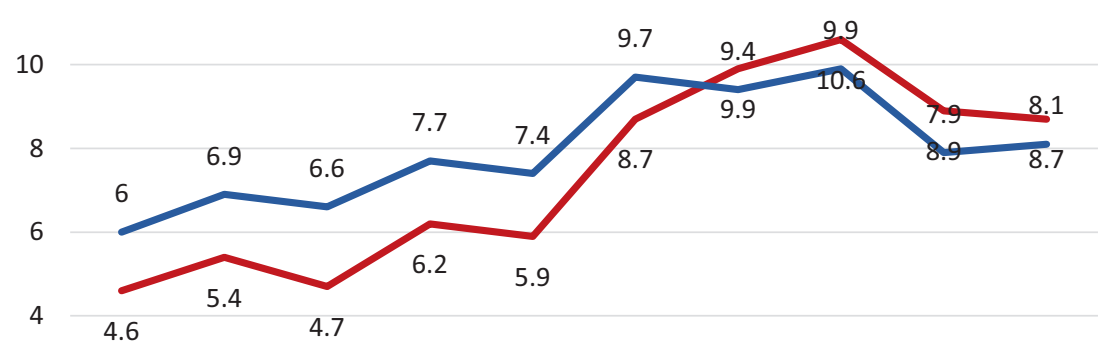

2

0

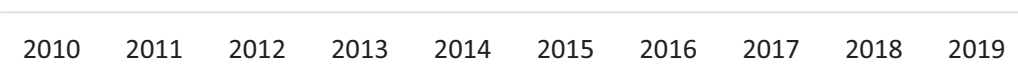

Fig. 2.2 At-work poverty risk by gender. (Source: Eurostat 2019e) 
poverty increased, suggesting that women's wages are less likely to move their and their families' living conditions above the poverty line than men's. Note that the women who are classified as poor in this chart may have been poor before 2016 as well, but they were not included in these statistics as they did not have paid employment. In the middle of the $2010 \mathrm{~s}$ they started to join the ranks of underpaid, precarious workers.

This underclass of women is heavily overrepresented among workfare workers. In an effort to eliminate what Prime Minister Orbán called a "welfare society", the Hungarian government boosted workfare programs to the point where close to 200,000 people participated at the peak in 2016. Workfare participants get paid a fraction of the minimum wage and typically work in menial jobs, which do not enhance their labor market chances (Cseres-Gergely and Molnár 2014). Studies suggest that in rural areas workfare opportunities are often allocated in exchange for political favors (Róna et al. 2020). Yet, workfare arrangements are popular because the alternatives are even worse. As noted before, the government has all but eliminated other forms of support for those who lost their jobs. And workfare has other advantages as well: it is a form of formal employment in reasonably regulated, typically single-shift, and occasionally part-time, conditions. These are job characteristics which are not easily available to low skilled workers. Importantly, given that workfare workers are in the formal economy, they also become eligible for tax benefits for children. As a result of all these and other labor market related factors, workfare programs have become feminized in the past years (Fekete 2021).

In summary, more women have been working for wages in the Hungarian economy in the late 2010s than at any time since the transition from state socialism but job growth was largest at the bottom of the occupational hierarchy, among the unskilled and also among those who work in the vastly underpaid government workfare programs. In addition to the opportunity to claim child benefits, women also occasionally choose workfare jobs over other types of employment because regular employmentshift work, informal work without contracts, the requirement to do unannounced overtime, the lack of control over the timing of the work period and the difficulty in finding part-time options-make it hard for women to reconcile childcare and paid work duties. In a recent study Dorottya Fekete (2021) asked workfare workers with children about their motivations. She found that what they appreciated most were the family benefits they gained access to, as well as the more family friendly work option of the possibility to work part time in single day time shifts. 
The COVID-19 pandemic of 2020-2021 further exposed the vulnerabilities of women's employment: in Hungary, as in many other countries around the world, more women lost their jobs than men. According to aggregate data from the Hungarian Statistical Office, between the end of 2019 and 2020 (the last quarter in each year), the employment rate of men aged between 15 and 64 in fact increased by $0.2 \%$ (even though the actual number of those employed declined somewhat), while women's rate decreased by $0.4 \%$. Job loss was more pronounced among those with less education, and among those employed in public works programs. However, even among the college-educated population where the number of the employed in fact continued to grow during the pandemic, men did significantly better than women, widening the employment gap within this group ( $\mathrm{KSH} 2021$ ). This is most likely explained by the extremely unequal division of care work which prevailed in this social stratum (Fodor et al. 2020). The "motherhood penalty", as this phenomenon is called, is the topic of the next section.

\section{Inequalities Among All: The Motherbood Penalty}

Hungary has the most generous set of parental leave and family benefits policies in Europe, yet also the fewest and most stingy work-life balance measures. Together with the requirement for mothers to be working for wages, this creates obvious inequalities. Indeed, as my calculations based on the Survey of Income and Living Conditions (EU SILC) data show, mothers of children under 16 years of age, net of other characteristicssuch as age, work experience, education, number of subordinates, work hours, marital status and whether or not they live in a multigenerational household-make less money than women without children. Fathers, in fact, experience a bonus over non-fathers. This was true in 2010, and the coefficient had increased statistically significantly by 2017: the motherhood penalty had grown. ${ }^{2}$

This is not surprising if we consider the dearth of policies aimed at supporting those with care responsibilities in the labor market. Researchers often talk about the reduction in labor rights during the Orbán era: strike

\footnotetext{
${ }^{2}$ The dependent variable was the log of income, individual variables are listed in the text. The variable of interest is the interaction between parental status and gender and I ran joint models for the two years with interaction terms to make sure that the change was significant. More information is available upon request.
} 
laws have been changed, overtime payment was reregulated to favor employers, unions were weakened and so on (Scheiring 2020). Rather less discussion has been dedicated to the extremely weak rights workers with care responsibilities have (for exceptions, see Gregor and Kováts 2019; Juhász 2012). Work hours in Hungary, as in other post-state-socialist societies, are higher than in most EU member states. Yet an extremely small number of people can work part time, only $4 \%$ in Hungary, one of the lowest rates in the EU. This is partly women's choice: wages are so low that a part-time salary is not enough to maintain a household. At the same time, even if they want to, it is difficult for women to negotiate part-time options with their employers (Fodor and Glass 2018; Glass and Fodor 2011). According to data from EIGE, the European Institute for Gender Equality, Hungarians are less likely to be able to set their own work hours than other EU states, and women, in particular, claim that they have no flexibility in this regard. In comparison to citizens of other EU countries Hungarians are less able than to adapt their work hours to external needs, they are less likely to be able to determine their own work hours and face difficulties when they need to take an hour or so off for personal reasons during the workday (EIGE 2019).

None of this is surprising as no consistent government incentive exists to prompt companies to enact work-life balance policies. Quite the opposite. In 2014, a new regulation was passed, which required that state administrators in one of the largest ministries (state department) and its local administrative offices work ten hours a day from 7:30 to 17:30. At the time, the minister in charge did not mince words when he claimed that "Our job has a beginning but it has no end, so this state department is unfortunately not a family friendly workplace" (János Lázár's speech in November 2014). The claim was preposterous, not only because of its lack of acknowledgment of the care work burden of his mostly female workforce, but also because Lázár ignored national legislation about compulsory work hours. Nevertheless, a ten-hour workday was instituted and was in effect for four years before it was rescinded, just as abruptly as it had been implemented. Note that this rule came to be applied to several other state institutions as well, all offering the type of pink-collar work that is typically understood as representing an opportunity for mothers to reconcile work and care responsibilities elsewhere. The Hungarian government did not exactly show a good example to privately owned companies, which clearly demonstrates its lack of dedication, attention and consideration to those with care responsibilities. 
Even during the pandemic, a relatively low number of people could work from home in Hungary, although more women did than men (Eurofound 2020). An OECD survey showed that, in general, Hungarian workplaces are not flexible in terms of work location: in 2015 fewer than $20 \%$ of mothers could do their jobs from a home office at least once during the year, placing Hungary into the bottom third of this distribution within Europe (OECD 2019). This is so even though quantitative and qualitative surveys demonstrate that women with care responsibilities would very much prefer to have this option available (Gregor and Kováts 2018).

Institutional childcare eases some of women's care burden. Kindergarten places for children over three years of age are fairly easily accessible in Hungary, with the exception of areas far from larger settlements. This is not the case for nurseries; although Orbán's government has dutifully utilized earmarked EU resources to build more child care institutions. This is reflected in a moderate increase in attendance over the past decade. In 2010 , over $90 \%$ of children under three years did not attend any formal childcare institution, while in 2019 only $83 \%$ did not, which is still far from the EU average of 35\% (Eurostat 2019f). In addition, childcare facilities are rather inflexible in opening hours: most close at $5 \mathrm{pm}$ and there is little leeway for extra hours or a different schedule. This constrains parents', mostly mothers', work time options.

Even when work-life policies do exist, their implementation is not necessarily automatic: women feel that they are asking for a personal favor. In a research project conducted with Christy Glass among professional mothers in Hungary we found that they do not consider part-time options (although legally guaranteed for women returning to work with children under three years) or parental leave policies (also enshrined in law) as true entitlements. Instead, they had to negotiate the terms of their leave, as well as their return, and were dependent on the goodwill of their supervisors. As a result, some women managed to get an arrangement that was acceptable and allowed them to balance work and family, while those whose supervisors were less understanding did not; in some cases this resulted in major breaks or shifts in women's careers (Fodor and Glass 2018). Personal connections and the importance of social capital are deeply embedded in Hungarian social institutions and history, which is one of the reasons why the women we interviewed did not find the necessity to negotiate legally mandated rights problematic. 


\section{Instead of Gender Equality Policy: Sentimentalization}

Through its anti-gender discourse and conspiracy theories about the EU's gender lobby, the government absolved itself of responsibilities regarding women's equal opportunities in the labor market. The quote at the beginning of the chapter from the Minister of Family Affairs reinforces this. Katalin Novak suggests that women should not be seeking equal wages to men; they should be content with the opportunity to be "real" women, to give birth and to take care of others. She is not alone in her open denial of the principle of equality. The President of the Hungarian Parliament argued this in 2019:

We should not overemphasize equality as that would mean the abolition of genders and in the end the rejection of femininity and women's virtues. (LaszlóKövér, in FICSAK 2019)

In other words, equality would threaten women's identity as women; femininity is essentially the opposite of gender equality. It is in this spirit that the Hungarian government has ignored EU-wide gender equality action plans, road maps and policy recommendations. A national-level round-table involving experts, NGOs and government officials on gender issues was discontinued, the section of the ministry which dealt with gender equality closed down, and the government first de-funded and then closed the Equal Opportunity Commission which had been designed to oversee problems related to gender-based discrimination, despite the fact that it is an EU requirement to have an EOC in place. The Hungarian Parliament has refused to ratify the Istanbul Convention on the elimination of violence against women, including domestic violence, and the Prime Minister has threatened to veto any EU regulation containing the word "gender", including the Action Plan for Gender Equality III.

I argue that instead of striving toward gender equality, the government has started to sentimentalize women's care work and closely confound it with women's identity as women. To illustrate I analyze quotations from a government funded publication in which men wrote laudations to women on the occasion of the International Day of Women in 2019. These were collected in a booklet and published by an organization called the Organization of the Club of Young Families (FICSAK 2019). (More on the publication in the methodological section of Chap. 1.) 
Practically each one of the quotes from top-level politicians published in the booklet mentions how women excel in care work, both in the home and in the workplace. As the Minister for Defense argues: "We think of women as the weaker sex, but they represent real spiritual power. They represent persistence, selfless dedication and love and all they expect in return is respect, attention, appreciation, love and kindness." Or in the words of the Minister of Human Affairs: "You [women] are caring, attentive, empathetic, beautiful. You give birth to children, you are the heart and soul of families." To quote a state secretary in the same ministry, "We need women to make our institutions, our communities, our families accepting, warm and caring". In all these cases womanhood is associated exclusively with caring and related attributes including kindness, devotion, gentleness, understanding and so on, and the production of these feelings in various communities is assigned to women and women alone. At the extreme, here is an example from a deputy minister who explicitly identified women's role as being men's primary support mechanisms. He wrote, "It is women who help hold the World together, and who we, men, can rely on day after day in our work, at home, in our communities".

The quotes associate women with acceptance, warmth, providing care and support, and none mention productivity, creativity or intelligence, even within these attributes. In the workplace too, women represent the very same qualities. "I want to thank my own female colleagues ... that they always suggest the possibility of a compromise not only in the family but in the workplace as well" chimes in a state secretary from the Ministry of Finance. Importantly, several men acknowledge the fact that it is hard work to be caring for a family and working for wages simultaneously. Women are expected to be overworked, and it is considered to be women's special skill to tolerate this. As a state secretary put it, "Only you [women] are able to do this: be a mother and a wife and at the same time do well in your job as well"; or in the words of another high-level male politician: "We often forget the many challenges women must face in our world today. They have to work for wages and must be perfect wives, mothers, problem solvers." "Nothing compares to women's performance. In addition to their visible-paid work ... [they also take care of their family]. ... This is hard work. It is a calling, rather than a simple job yet they do it smiling, without complaint, naturally" (Minister of Finance).

Although the men acknowledge the exceptionally hard work women do, note the multiple references to a calling, rather than a form of skill or hardship that requires or warrants compensation. "Being a woman is more 
than a simple task. It is a calling" repeats one of the state secretaries of the Parliament. Women are due respect and appreciation but not tangible rewards. The politicians here sentimentalize women's work: they elevate it to the level of a calling, where financial incentives and rewards seem meaningless. Let us end this section with the words of Hungary's young Minister of Finance, who seems to be familiar with the term "invisible work" and acknowledges that women do most of it, both in the family and in the workplace. But "they do this out of the kindness of their hearts without expecting remuneration of any form, simply because they consider it the right thing to do".

In Hungary's carefare regime, femininity is closely tied to selfless care work within and outside the family setting. Men take part at their pleasure, but care is women's primary responsibility. The work is much appreciated, it is considered important and socially valuable, but not remunerable. Care work is sentimentalized rather than commercialized.

\section{Conclusion}

I have argued that a new response is emerging to the crisis of care in Hungary. The policy direction I call "carefare" aims to eliminate the contradiction between intensifying production and the need for reproduction by piling additional work burden on the shoulders of women and taming their possible reluctance by discursively connecting femininity to care work.

As several researchers have pointed out, the role of the state in managing the economy, society and redistribution is extremely important in antiliberal Hungary (Magyar 2016; Scheiring 2020). From this position, the government has made good political use of Hungarians' long-standing anxieties about the disappearance of their bloodline and the death of the national culture due, allegedly, to women's reluctance to reproduce. Demographic revival was placed on the agenda of the Orbán government immediately upon gaining power in 2010 and it became its true focal point after 2015. As a consequence, over the past decade, the Parliament has passed a whole slew of policy measures to encourage births, specifically to encourage births to heterosexual, married, working families. In the process, the state has created a carefare regime: encouraged women to have children, and do most of the associated care work, while simultaneously constructing them as second-class, female workers on the paid labor market. Claims to social citizenship are now most successfully made on the basis of parental and work status combined. 
This move toward a carefare regime has a number of consequences that are already visible: the most important is the growing underclass of female workers who work for extremely low wages in exchange for being able to maintain their labor market status while also taking care of their dependents. I also noted the increased work burden that a higher level of reproduction-within the context of the unequal distribution of care work-means for women.

At the same time, carefare provides political capital to the Orbán regime: it functions as a mechanism to lessen the pain of increasing social inequalities. Especially among the lower middle classes, women's extra work may buy households out of poverty, or at least allow them a degree of upward mobility, even though this may be limited or fragile. Economic growth has resulted in a significant increase in class inequalities in Hungary, although some resources have trickled down to certain groups of the population, especially to families with children with some attachment to the formal labor market. They are some of the government's most loyal supporters and the voters who brought FIDESZ into power (Róna et al. 2020). Their families are doing better financially under the FIDESZ regime, thanks, in part, to the wide range of "family protection" measures available to them in the form of loans and government grants.

The most positive development has been that the poverty rate of children has declined rapidly during the last few years in Hungary. In 2011 the poverty risk of a family with three children was a shocking $35 \%$, but now it stands at $11.4 \%$, one of the lowest in the European Union (Eurostat 2020). The same pattern is visible among families with fewer children, bringing the poverty risk of children down to levels below the EU average (ibid.). At the same time, however, the poverty risks of single people, of the elderly, especially elderly women, have all skyrocketed: they have been left out of the government provided windfall. While the reduction of child poverty is laudable, it should be noted that less than half of all households have children, fewer than a quarter have two or more children, and an increasing number of people are living alone. For them the carefare regime has little to offer.

In conclusion, carefare regimes come with political benefits to antiliberal governments. Carefare eases some of the social tension which results from a rapid increase in social inequalities, obvious corruption and cronyism. By redistributing a sizeable, but still relatively small, amount of resources to a select group of "deserving" families, by increasing their social mobility chances, even if to a significantly lesser degree than that of 
families at the top of the social hierarchy, the government buys the loyalty of an important constituency. What we must not forget is that this is happening on the back of women, on the condition of women's increased contribution to care work and compromise in work options.

In addition, upward mobility, even among those most favored by government policy, may be fragile. Over a third of all marriages end in divorce ${ }^{3}$ in Hungary and the small steps toward upward mobility may fall away quickly as divorcing couples have to share responsibilities for mortgages and loans, or when the promised number of children do not arrive, or as the job market ebbs and family income dwindles to the point where meeting interest payments becomes problematic. In this context women's sacrifice will be even more starkly visible.

\section{REFERENCES}

Andorka, Rudolf. 1975. Az ormánsági születéskorlátozás története [The History of Birth Control in Ormansag]. Valosag, no. 6.

Blaskó, Zsuzsa. 2011. 'Hároméves Kor Alatt Mindenképpen Megsínyli?’- Interjús Kutatás Kisgyermekes Anyák Körében ['She Will Suffer under Age 3, No Matter What': Interview Study among Women with Small Children]. In Szerepváltozasok [Changing Roles], ed. Ildikó Nagy and Tiborné Pongrácz. Budapest: TARKI.

Cseres-Gergely, Zsombor, and György Molnár. 2014. Közmunka, segélyezés, Eesődleges és másodlagos munkaerőpiac [Public Works, Aid, Primary and Secondary Labor Market]. In Társadalmi Riport [Social Report], ed. Tamás Kolosi and Tóth István György, 204-225. Budapest: TARKI.

Ehrenreich, Barbara, and Arlie Russel Hochschield. 2004. Global Woman: Nannies, Maids, and Sex Workers in the New Economy. New York: Holt Paperbacks.

England, Paula. 2005. Emerging Theories of Care Work. Annual Review of Sociology 31 (1): 381-399.

Eurofound. 2020. "Living, Working and COVID-19." COVID-19. Luxembourg: Publications Office of the European Union.

Falussy, Béla, and István Harcsa. 2000. Háztartás És Háztartásgazdaság Az Időfelhasználás Tükrében. In Társadalmi Riport 2000 [Social Report], ed. Tamás Kolosi, István György Tóth, and György Vukovich. Budapest: TARKI.

Fekete, Dorottya. 2021. 'Nekem ez most jó a kislány végett': Nói tapasztalatok a közfoglalkoztatási programról. [This is good for me now because of my daugh-

${ }^{3}$ Of couples who married in 2000, over a third got divorced within 15 years (Makay and Szabó 2018). 
ter: women's experience in public works programs]. Szociológiai Szemle 30 (3): 70-95.

FICSAK. 2019. Nöi Lélek Férfiszemmel [Women's Soul Through Men's Eyes. http:// www.kiralynora.hu/2018/03/01/noi-lelek-ferfi-szemmel/.

Fodor, Eva. 2003. Working Difference: Women's Working Lives in Hungary and Austria, 1945-1995. Durham, NC: Duke University Press.

Fodor, Eva, and Christy Glass. 2018. Negotiating for Entitlement: Accessing Parental Leave in Hungarian Firms. Gender, Work and Organizations 25 (6): 687-702.

Fodor, Eva, Christy Glass, Janet Kawachi, and Livia Popescu. 2002. Family Policies and Gender in Hungary, Poland, and Romania. Communist and PostCommunist Studies 35 (4): 475-490.

Fodor, Eva, Anikó Gregor, Júlia Koltai, and Eszter Kováts. 2020. The Impact of COVID-19 on the Gender Division of Childcare Work in Hungary. European Societies, September, 1-16.

Fraser, Nancy. 2016. Contradictions of Capital and Care. New Left Review 100: 99-117.

Geambasu, Réka, Orsolya Gergely, Beáta Nagy, and Nikolett Somogyi. 2021. Qualitative Research on Hungarian Mothers' Social Situation and Mental Health During the Time of the Covid-19 Pandemic. Corvinus Journal of Sociology and Social Policy 11 (2): 151-155.

Glass, Christy, and Eva Fodor. 2011. Public Maternalism Goes to Market: Recruitment, Hiring and Promotion in Postsocialist Hungary. Gender \& Society 25 (1): 5-26.

Gregor, Anikó, and Eszter Kováts. 2018. Nöügyek 2018. Társadalmi problémák és megoldási stratégiák: a kutatási eredmények összefoglalója. [Women's Issues 2018: Social Problems and Solution Strategies, Research Report]. Budapest: Friedrich Ebert Stiftung.

- 2019. Work-Life: Balance? Tensions between Care and Paid Work in the Lives of Hungarian Women. Socio.hu, Special issue 9: 91-115.

Haney, Lynne. 2002. Inventing the Needy: Gender and the Politics of Welfare in Hungary. Berkeley, CA: University of California Press.

- 2003. Welfare Reform with a Familial Face Reconstituting State and Domestic Relations in Post-Socialist Eastern Europe. In Families of a New World, ed. Lynne Haney and Lisa Pollard, 159-178. New York, London: Routledge.

Harvey, David. 2015. Seventeen Contradictions and the End of Capitalism. London: Profile Books.

Hegedűs, Mihály. 2020. Rejtett gazdaság és a Covid-19 járvány összefüggései [The Relationship Between the Hidden Economy and Covid 19]. Economica $11(3-4): 1-10$. 
Heller, Mária, Dénes Némedi, and Ágnes Rényi. 2015. Népesedési viták Magyarországon 1960-1986. [Population debates in Hungary, 1960-1986]. KSH Népesedéstudományi Intézet. https://www.demografia.hu/kiadvanyokonline/index.php/kutatasijelentesek/issue/view/385.

Hochschield, Arlie Russel. 1983. The Managed Heart: Commercialization of Human Feeling. Berkeley, CA: University of California Press.

HVG. 2020. Novak Katalin üzenete a nöknek [Katalin Novak'smessagetowomen]. December 14. https://hvg.hu/elet/20201214_Novak_Katalin_uzenete_a_ noknek_Ne_zavarja_oket_hogy_kevesebbet_keresnek_mint_a_ferfiak. Accessed 23 April 2021.

Isaksen, Lise Widding, Sambasivan Uma Devi, and Arlie Russell Hochschild. 2008. Global Care Crisis: A Problem of Capital, Care Chain, or Commons? American Behavioral Scientist 52 (3): 405-425.

Jarvis, Sarah J., and John Miklewright. 1992. The Targeting of Family Allowance in Hungary. Fiesole: European University Institute.

Javornik, Jana. 2014. Measuring State De-Familialism: Contesting Post-Socialist Exceptionalism. Journal of European Social Policy 24 (3): 240-257.

Jessop, Bob. 2019. Authoritarian Neoliberalism: Periodization and Critique. South Atlantic Quarterly 118 (2): 343-361.

Juhász, Borbála. 2012. Orbán's Politics - a Gender Perspective. Working paper. Friedrich Ebert Stiftung. http://www.fesbp.hu/common/pdf/Nachrichten_ aus_Ungarn_1_2012.pdf.

Kapitány, Balázs, Zsolt Spéder, Judit Monostori, Péter Öri, and Zsolt Spéder. 2019. Fertility. In Demographic Portrait of Hungary 2018. Budapest: Hungarian Demographic Research Institute.

Magyar, Balint. 2016. Post-Communist Mafia State: The Case of Hungary. Budapest: CEU Press.

Mahon, R. 2002. Child Care: Toward What Kind of 'Social Europe'? Social Politics Fall: 343-379.

Makay, Zsuzsanna. 2018. Családtámogatás, női munkavállalás [Family Support, Women's Work Engagement]. In Demográfiai Portré, ed. Judit Monostri, Péter Ori, and Zsolt Spéder, 83-102. Budapest: KSH NKI.

Makay, Zsuzsanna, and Laura Szabó. 2018. Válás. [Divorce]. In Demográfiai Portré 2018 [Demographic Portrait], ed. Judit Monostori, Péter Ori, and Zsolt Spéder, 29-45. Budapest: KSH NKI.

Mandel, Hadas, and Moshe Semoyonov. 2006. A Welfare State Paradox: State Interventions and Women's Employment Opportunities in 22 Countries. American Journal of Sociology 111: 1910-1949.

Melegh, Attila. 2019. The Fear of Population Replacement. In Brave New Hungary: Mapping the "System of National Cooperation", ed. Kovács János Mátyás and Trencsényi Balázs. Lanham, MD: Rowman and Littlefield. 
Monostori, Judit, and Gabriella Gresits. 2018. Idősödés. In Demográfiai Portré 2018 [Demographic Portrait], ed. Judit Monostori, Péter Ori, and Zsolt Spéder, 127-145. Budapest: KSH NKI.

Morgan, Kimberly J., and Kathrin Zippel. 2003. Paid to Care: The Origins and Effects of Care Leave Policies in Western Europe. Social Politics 10: 49-85.

Peck, Jamie, and Nik Theodore. 2012. Reanimating Neoliberalism: Process Geographies of Neoliberalisation. Social Anthropology 20 (2): 177-185.

Petit, Becky, and Jennifer L. Hook. 2009. Gendered Tradeoffs: Family, Social Policy, and Economic Inequality in Twenty-One Countries. New York: Russell Sage Foundation.

Pongráczné, Marietta. 1999. Terhességmegszakítások a számok és a lakossági vélemények tükrében [Popular Views on Abortion]. Századvég 15 (59). http:// www.c3.hu/scripta/szazadveg/15/pongracz.htm. Last accessed 21 Oct 2021.

Rat, Cristina, and Dorottya Szikra. 2018. Family Policies and Social Inequalities in Central and Eastern Europe: A Comparative Analysis of Hungary, Poland and Romania between 2005 and 2015. In Handbook of Family Policy. Cheltenham: Edward Elgar Publishing.

Róna, Dániel, Eszter Kováts, Judit Pétervari, Blanka Szeitl, and Márton Tury. 2020. A FIDESZ Titok: Gazdasági Szavazás Magarországon [The Secret of FIDESZ: Vote by Economic Interest in Hungary]. Budapest: 21 Kutatóközpont.

Rose, Nikolas. 1998. Inventing Our Selves: Psychology, Power, and Personhood. Cambridge MA: Cambridge University Press.

Sandberg, Sheryl. 2013. Lean in Women, Work and the Will to Lead. New York: Knopf.

Saxonberg, Steven, and Tomas Sirovatka. 2006. Failing Family Policy in PostCommunist Europe. Journal of Comparative Policy Analysis 8: 351-379.

Scharle, Agota, and Dorottya Szikra. 2015. Recent Changes Moving Hungary Away from the European Social Model. In The European Social Model In Crisis. Is Europe Losing Its Soul? ed. Daniel Vaughan-Whitehead. Cheltenham: Edward Elgar.

Scheiring, Gábor. 2020. The Retreat of Liberal Democracy: Authoritarian Capitalism and the Accumulative State in Hungary. Challenges to Democracy in the 21st Century. London: Palgrave Macmillan.

Shire, Karen A., and Kumiko Nemoto. 2020. The Origins and Transformations of Conservative Gender Regimes in Germany and Japan. Social Politics 27 (3): 17.

Spéder, Zsolt, Lívia Murinkó, and Livia Sz. Oláh. 2020. Cash Support vs. Tax Incentives: The Differential Impact of Policy Interventions on Third Births in Contemporary Hungary. Population Studies 74 (1): 39-54.

Szelewa, Dorota, and Michal P. Polakowski. 2008. Who Cares: Changing Patterns of Childcare in Central and Eastern Europe. Journal of European Social Policy 18: 115-131. 
Szikra, Dorottya, and Dorota Szelewa. 2010. Do Central and Eastern European Countries Fit the 'Western' Picture?: The Example of Family Policies in Hungary and Poland. In Welfare States and Gender in Central and Eastern Europe: Continuity and Post-Socialist Transformation in the EU Member States, ed. Christina Klenner and Simone Leiber, 81-116. Brussels: ETUI.

Utrata, Jennifer. 2015. Women Without Men: Single Mothers and Family Change in the New Russia. Ithaca, NY: Cornell University Press.

Wacquant, Loïc. 2012. Three Steps to a Historical Anthropology of Actually Existing Neoliberalism. Social Anthropology 20 (1): 66-79.

Walby, Sylvia. 2020. Varieties of Gender Regimes. Social Politics: International Studies in Gender, State \& Society 27 (3): 414-431.

\section{LIST OF DATA AND MEDIA SOURCES}

EIGE. 2019. Flexible work arrangements. https://eige.europa.eu/publications/ gender-equality-index-2019-report/flexible-working-arrangements. Accessed 14 Feb 2021.

Erdély.ma. 2018. Választás 2018-Orbán: Nekünk gyerekek kellenek, nem migránsok [Election 2018- Orbán: We need children, not migrants]. March 4. https:// www.erdely.ma/valasztas-2018-orban-nekunk-gyerekek-kellenek-nemmigransok/. Accessed 12 Feb 2021.

EUROSTAT. 2018a. Fertility Indicators: Total Fertility Rate. https://ec.europa. eu/eurostat/databrowser/view/demo_find/default/table?lang=en. Accessed 12 Feb 2021.

. 2018b. Life Expectancy by Age and Sex. https://ec.europa.eu/eurostat/ databrowser/view/demo_find/default/table?lang=en. Accessed 12 Feb 2021.

_. 2019a. Government Expenditure by Function. https://ec.europa.eu/ eurostat/databrowser/view/gov_10a_exp/default/table?lang=en. Accessed 12 Feb 2021.

- 2019b. Employment and Activity by Sex and Age. https://ec.europa.eu/ eurostat/databrowser/view/lfsi_emp_a/default/table?lang=en. Accessed 14 Feb 2021.

- 2019c. Labor Market Transition - Annual Data. https://ec.europa.eu/ eurostat/databrowser/view/LFSI_LONG_A__custom_564914/default/ table?lang=en. Accessed 14 Feb 2021.

- 2019d. Mean Annual Earning by Sex, Economic Activity and Educational Attainment. https://ec.europa.eu/eurostat/databrowser/view/earn_ ses18_30/default/table?lang=en. Accessed 13 Feb 2021.

2019e. In-Work at-Risk-of-Poverty Rate by Age and Sex. https://ec. europa.eu/eurostat/databrowser/view/ILC_IW01__custom_565060/ default/table?lang=en. Accessed 14 Feb 2021. 
2019f. Children in Formal Childcare or Education by Age Group and Duration. https://ec.europa.eu/eurostat/databrowser/view/ILC_CAIND FORMAL_custom_490064/default/table?lang=en. Accessed 14 Feb 2021.

. 2020. At-Risk-of-Poverty Rate by Poverty Threshold and Household Type. https://ec.europa.eu/eurostat/databrowser/view/ilc_li03/default/ table?lang=en. Accessed 14 Feb 2021.

Hornyák, József. 2019. Sosem látott számok: kiderült, mennyien dolgoznak minimálbérért Magyarországon. Portfolio online, January 7. https://www.portfolio.hu/gazdasag/20190107/sosem-latott-szamok-kiderult-mennyiendolgoznak-minimalberert-magyarorszagon-309419. Accessed 13 Feb 2021.

KSH. 2012. Időmérleg 2009/2010: Összefoglaló adattár. Budapest, KözpontiStatisztikaiHivatal. https://www.ksh.hu/docs/hun/xftp/idoszaki/ idomerleg/idomerleg0910.pdf. Accessed 10 Feb 2021.

— 2019a. Népesség, Népmozgalom 1900-. Teljestermékenységiarány, élveszületések, terhességmegszakitások, halálozás. Budapest: Központi Statisztikai Hivatal. https://www.ksh.hu/docs/hun/xstadat/xstadat_hosszu/h_wdsd001b.html. Accessed 10 Feb 2021.

. 2019b. A Magyarországra érkezett menedékkérök száma állampolgárság szerint, 2000. Budapest: Központi Statisztikai Hivatal. https://www.ksh.hu/ docs/hun/xstadat/xstadat_eves/i_wnvn002b.html. Accessed 10 Feb 2021.

—. 2019c. A gyermekeknapközbeniellátása. StatisztikaiTükör, April 12, 2019. Budapest: KözpontiStatisztikaiHivatal. https://www.ksh.hu/docs/hun/xftp/ stattukor/kisgyermnapkozbeni/kisgyermnapkozbenil8.pdf.

- 2020. Élveszületések, 2019, 2020. Budapest: KözpontiStatisztikaiHivatal. https://www.ksh.hu/docs/hun/xstadat/xstadat_evkozi/e_wns001.html. Accessed 12 Feb 2021.

—. 2021. A foglalkoztatottak száma legmagasabb iskolai végzettségük szerint, nemenként. https://www.ksh.hu/docs/hun/xstadat/xstadat_evkozi/e_ qlf007.html. Accessed 12 Feb 2021.

Magyar Nemzet. 2020. Erősödik az egyházak szerepe a szociális ágazatban. July 22. https://magyarnemzet.hu/belfold/erosodik-az-egyhazak-szerepe-aszocialis-agazatban-8412339/

OECD. 2019. Family Database, "Public Spending on Family Benefits". http:// www.oecd.org/els/family/database.htm\#public_policy. Accessed 12 Feb 2021.

Portfolió. 2021. Farkas András: Hihetetlenhungarikum: százezrekveszítenek a minimálnyugdíjbebetonozásával, akiknemnyugdíjasok [Thousands lose out as the government fixes the minimum pension, even those who are not pensioners]. Portfolio online, January 6. https://www.portfolio.hu/gazdasag/ $20210106 /$ hihetetlen-hungarikum-szazezrek-veszitenek-a-minimalnyugdijbebetonozasaval-akik-nem-is-nyugdijasok-463908. Accessed 10 Feb 2021.

Rosen, Ruth. 2007. "The Care Crisis." The Nation, 2007, March 12, 2007 edition. https://www.thenation.com/article/archive/care-crisis/.

Williams, Fiona. 2018. "A Global Crisis of Care?” Global Dialogue, 2018. 
Open Access This chapter is licensed under the terms of the Creative Commons Attribution 4.0 International License (http://creativecommons.org/licenses/ by $/ 4.0 /$ ), which permits use, sharing, adaptation, distribution and reproduction in any medium or format, as long as you give appropriate credit to the original author(s) and the source, provide a link to the Creative Commons licence and indicate if changes were made.

The images or other third party material in this chapter are included in the chapter's Creative Commons licence, unless indicated otherwise in a credit line to the material. If material is not included in the chapter's Creative Commons licence and your intended use is not permitted by statutory regulation or exceeds the permitted use, you will need to obtain permission directly from the copyright holder. 